\title{
Case Report on Excision of Scwahnnoma of Hard Palate
}

\author{
Tofiq Hakimuddin Bohra*, Ajinkya Vyavhare and Janaki Iyer \\ Apex Multispeciality Hospital and Iccu, India
}

Submission: October 04, 2017; Published: October 16, 2017

*Corresponding author: Tofiq Hakimuddin Bohra, Apex Multispeciality Hospital and Iccu, Mumbai, India, Email: drtofiqbohra@gmail.com

\section{Introduction}

Schwannomas, also known as neurilemomas or neurilemmomas, are uncommon and slow-growing benign tumors. Whereas, about one-third of all extra cranial Schwannomas are found in the head and neck region, a few intraoral Schwannomas are reported in the literature [1]. It is a painless, slow growing mass with a smooth surface. schwannoma mainly has predilection for the second and third decade of life [2]. The prognosis for such lesions is good and turning into malignancy is rare. These benign tumours are easily mistaken for other entities such as pleomorhic adenoma and lipoma because they are also slow growing and do not show any neural symptoms, palatal abscess, fibroma/papilloma, mucous retention cyst, minor salivary gland tumour, lymphoma, squamous cell carcinoma on account of their site of occurance can also be mistaken for schwannoma. Biwas et al. [3] reviewed a series of 31 cases of extracranial head and neck schwannomas during a 10-year period, only one case was in the hard palate [3]. This case report discusses a case of right side schwannoma of the hard palate and the surgical procedure followed.

\section{Case Report}

A 19 yrs of age boy reported to our department with a complain of slow growing painless mass which he had observed around 7 months ago and has been growing since then. On examination the swelling was over the right side hard palate region, measuring around $3 \mathrm{~cm} \times 5 \mathrm{~cm}$. The mucosa on the top of the lesion was inflamed. The mass was firm mildly tender and fixed, no lymphadenopathy was noted. Patient did not give any medical history of concern or history of any habits. A computed tomography scan was advised to the patient that revealed a mass with little bone erosion on the palatal surface of the right side. Provisional diagnosis was made as mucous retention cyst or minor salivary gland tumour and the treatment plan was prepared for wide local excision of the mass.
The patient was taken under general anaesthesia for the above mentioned procedure; right side full thickness palatal mucosal flap was raised to identify the mass. The mass was dissected from the greater palatine bundle as it had grown around the bundle. Irrigation done using saline and beta dine and a palatal stent placed in situ with the help of wires which was made pre operatively. The stent was left in place for 1 week post- operatively and the patient followed up after 1 month, revealed no swelling or re-occurrence locally. Histo-pathological reports revealed encapsulated tumour composed of fascicles of spindle cells exhibiting alternate cellular and hypo cellular areas (Antonio A and Antoni B). With immunohistochemistry (IHC), S-100 was positive and smooth muscle antigen (SMA) was negative in the tumor cells. The diagnosis of Schwanomma was given.

\section{Discussion}

Theodor Schwann (1810-82) was a German anatomist, physiologist and co founder of cell therapy; he was the first one to name Schwann cells of the peripheral nerve sheath. Schwannoma derived its name because this neoplasm was thought to originate from the Schwann cells of the peripheral nerve sheath. In 1908, Jose Verocay provided the first microscopic description of this tumour and suggested the designation 'Neurinoma'. In 1935, Arthur Stout coined the term 'Neurilemmoma'. In 1940, on the basis of light microscopic studies, Isadore Max Tarlov proposed this tumor to be of fibroblastic origin and coined the term 'per neural fibro blastoma'. Today, most pathologists consider the terms schwannoma, neurinoma, neurilemmoma, and perineural fibroblastoma to be synonymous and distinguish this lesion from neurofibroma [4].

Schwannomas occur in head and neck regions but are a rare entity to be diagnosed in the hard palate, the other most common areas include buckle mucosa, tongue, lips, and floor of 
the mouth. Schwannoma has a higher predilection for females as compared to males, however the case report here has a male patient $[2,3]$. William et al. showed that schwannomas have a predilection for males, while in the study of Lucas, there was a greater predilection for females. Sahoo et al. [4] in their article have stated that there was no gender prediliction in their review [4]. Schawannoma signs and symptoms generally do not include pain because generically this is a bening growth, but it may lead to serious discomfort if present in the tongue or the floor of the mouth as it may lead to dysphagia or difficulty in breathing. In this case the swelling was present on the hard palate and the patient had difficulty in eating as well as talking as the tongue mobility was getting compromised because of the swelling on the palate. This swelling if present around the nerve can result in paraesthesia, but in the case discussed there was no paraesthesia [3]. On occasion, the tumour arises centrally with in bone and may produce bony expansion. Intraosseous schwannomas are most common in the posterior mandible and usually appear as either unilocular or multilocular radioluciencies on radiographs [5].

There are three mechanisms by which schwannomas may involve bone: they may arise centrally within bone, they may arise within the nutrient canal and produce canal enlargement, or a soft tissue or periosteal tumor may cause secondary erosion and penetration into bone [6]. Clinically there are two forms of schwannomas, out of which encapsulated type is the most frequent, this type of swelling resembles a fibroma [7]. Histological, schwannomas are made up of two distinct regions Antoni A and Antoni B . Palisading trabeculae of spindle-shaped Schwann cells are found in Antoni A [8]. Cells are loose and hypocellular, and the Schwann cells appear polymorphic in Antoni B type [9]. Immunohistochemistry study of schwannomas show an intense and uniform staining for S-100 protein, which is a marker for schwann cells. These cells also express vimentin, Lev [7] antigen and glial fibrillary acidic protein [3]. Elongated cells are present in both neurofibroma and schwannoma, but histologically and histogenitically, the schwannoma is derived from the schwan cells where as the neurofibroma from the fibroblasts of the perineurium. Neurofibroma is unencapsulated, consisting of a mixture of Schwann cells, perineural cells and endoneurial fibroblasts $[10,11]$. Computed tomography, magnetic resonance imaging, and ultra sonography are the best imaging modalities for differential diagnosis of the swelling ocuuring anywhere in the oral cavity.

\section{Conclusion}

Schwannoma of the oral cavity involving the hard palate is a rare occurrence, which we do not come across in our day to day clinical practice. A benign fixed swelling in this region should be differentiated from other tumors present commonly in this anatomical region, and schwannoma should be considered in the differential diagnosis even though being a rare tumor. The prognosis of this lesion is very good with low rate of reoccurrence. We have a follow up of this patient for a year

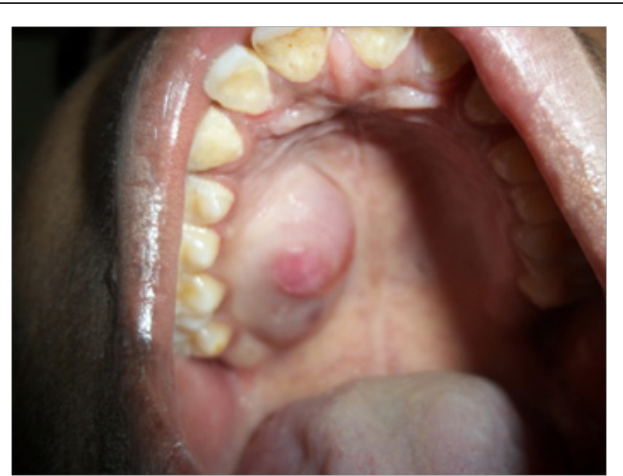

Figure 1: Pre operative hard palate swelling aprroaching mid line.

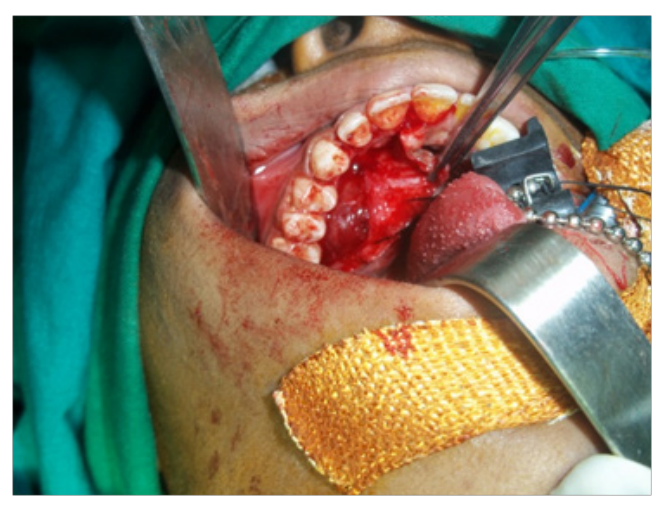

Figure 2: Intra operative view of lesion.

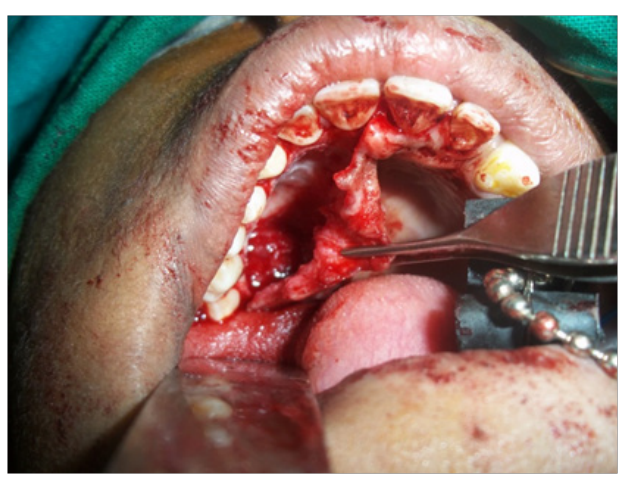

Figure 3: Intra operative image after excision of lesion keeping the greater palatine bundle intac.

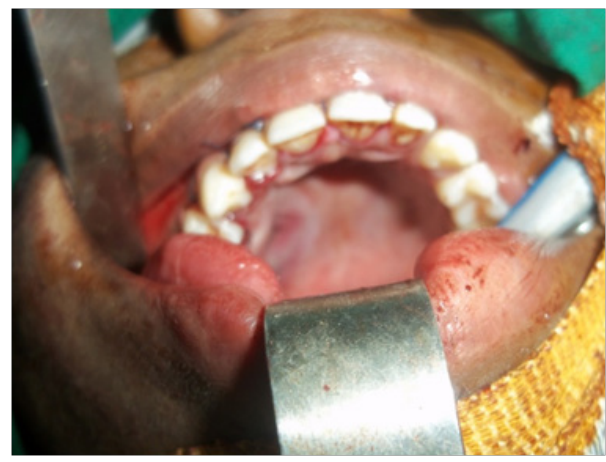

Figure 4: Post operative view after palatal stent placement. 


\section{References}

1. Jörg Handschel, Sebastian Heikaus, Rita Depprich, Norbert R kubler, Sareh Said Yekta, et al. (2012) Intraoral Schwannoma: Review of the Literature and Presentation of a Rare Case. The Journal of Craniomandibular practice 30(2): 150-153.

2. Monir Moradzadeh Khiavi, Ali Taghavi Zenouz, Ali Hossein Mesgarzadeh, Omid Sabetmehr, Seyyed Mostafa Mahmoudi, et al (2014) Schwannoma in the Midline of Hard Palate: A Case Report and Review of Literature. J Dent Res Dent Clin Dent Prospects 8(2): 114117.

3. Biswas D, Marnane CN, Mal R, Baldwin D (2007) Extracranial head and necks schwannomas: a 10-year review. Auris Nasus Larynx 34(3): 353359.

4. Pradyumna Kumar Sahoo, Pradyumna Kumar Sahoo, Palash Kumar Mandal, Saradindu Ghosh (2014) schwannoma of hard palate. Natl J Maxillofac Surg 5(1): 39-41.

5. Prasanna Kumar D, Meghashri K (2012) Schwannoma of the hard palate: A case report and review of literature. Journal of Advanced Oral Research 3(1): 30-34.
6. Santos PP, Freitas VS, Pinto LP, Freitas Rde A, de Souza LB (2010) Clinicopathologic analysis of 7 cases of oral schwannoma and review of the literature. Ann Diagn Pathol 14(4): 235-239.

7. López-Carriches C, Baca-Pérez-Bryan R, Montalvo-Montero S (2009) Schwannoma located in the palate: Clinical case and literature review. Med Oral Patol Oral Cir Bucal 14(9): e465-e468.

8. Amir R, Altman KW, Zaheer S (2002) Neurilemmoma of the hard palate. J Oral Maxillofac Surg 60(9): 1069-1071.

9. Martins DM, Jesus LA, Fernandes SPK, Bussadori KS, Taghloubi AS, et al. (2009) Intraoral schwannoma: Case report and literature review. Indian J Dent Res 20(1): 121-125.

10. Zachariades N, Skoura C, Papageorgiou G, Chrissomali E (2001) Giant ancient neurilemmoma of the cervical region: Report of case. J Oral Maxillofac Surg 59(6): 668-672.

11. Prasanna Kumar D, Meghashri K (2012) Schwannoma of the hard palate: A case report and review of literature. Journal of Advanced Oral Research 3(1): 30-34.

\section{Your next submission with Juniper Publishers} will reach you the below assets

- Quality Editorial service

- Swift Peer Review

- Reprints availability

- E-prints Service

- Manuscript Podcast for convenient understanding

- Global attainment for your research

- Manuscript accessibility in different formats

( Pdf, E-pub, Full Text, Audio)

- Unceasing customer service

Track the below URL for one-step submission https://juniperpublishers.com/online-submission.php 